\title{
殺虫剂の作用機構研究の新技法
}

I. 昆虫の初代培養を利用した殺虫剂のアッセイ法

\author{
清 水 利 昭* \\ 筑波大学農林学系 \\ （昭和 54 年 3 月 1 日受理）
}

\section{Advanced Methods for Studying Mode of Action on Insecticides}

\section{Insect Primary Tissue Culture for Insecticides Assay}

\author{
Toshiaki SHIMizU \\ Institute of Agriculture and Forestry, The Tsukuba University, \\ Ibaraki 300-31, Japan
}

\begin{abstract}
細胞培養，組織培養のメリットとしては，昆虫の体か ら生きたままの細胞, 組織をとり出し, ガラス器の中で 培養し, 化学薬品, ホルモン, ウイルス等の直接的な作 用を単純な系で調べることができるという点があげられ る. 最近, 組織培養は, 従来の知見をもとに毒性（残 留, 催奇性), 薬理, 代謝試験にまで応用されてきている. Murakami ${ }^{1 \sim 5)}$ らはヒトの培養細胞を使って各種農薬や 化学物質のとり込み, 残留, 代謝について調べている.

ここでは，最初に培養組織の評価の指標を述べ, 次に， キチン合成とその阻害剤との関係や精巣の培養を紹介 し，ホルモンや殺虫剤について解説したい。とくに精巣 の培養は, 器官培養と生殖細胞の培養を兼䃿ているとこ ろに興味がある。
\end{abstract}

\section{1．組織の変化の何を指標とするか？}

一般に農薬の検定を行なうためには，培地に薬剤を添 加し，日を追って組織の変化を調べる方法がとられてい るが, 初代培養の欠点は, 定量的な取り扱いが困難なこ とがあげられる.これを補うためには次のような項目を メルクマールとして採用するとよいと思われる。

1）形態的変化を経時的に位相差顕微鏡で観察する. 未分化なたは胚性組織の場合は生育 (growth) や分化

* 元理化学研究所研修員 (differentiation)を，すでに成熟した組織の場合には，成 長よりも維持 (maintenance) を指標とする.

2）固定, 脱水, 染色して組織学的・組織化学的研究 に供する．超薄切片にして電子顕微鏡観察に供する．標 識物質をとり込ませて， ミクロオートラジオグラフィー をとることもできる.

3）細胞蛋白質 (一般的な定量法として Lowry 法6) を組織培養研究用に改変した Oyama と Eagle ${ }^{7)}$ の方法 がよく用いられている.)，核酸等の細胞内主要成分を生 化学的に測定する. DNA, RNA, 蛋白質生合成の前駆 体である thymidine, uridine, あるいはアミノ酸などを 標識し，その標識物質をとり込ませ，核酸および蛋白質 生合成の抑制度を測定する.

4）細胞培養の場合には，細胞数や細胞核数を血球計 算板や電気式細胞数測定器を用いて測定する.

5）細胞, 組織の面積, 容積を測定する.

6）酵素活性や呼吸量の測定, あるいは培地の化学的 変化を測定する.

\section{2. キチンとキチン合成阻害剤}

Table 1 は Sowa そ Marks (1975)8) によるゴキブリ (Leucophaea maderae) の再生組織を $\beta$-エクダイソンを 含む培地で培養し，キチン合成を促す条件下（ゴキブリ の再生組織では $\beta$-エクダイソンを含む培地でキチンへ 
Table 1 The in vitro assay systems for testing chitin biosynthesis inhibitors.

\begin{tabular}{cllll}
\hline \multicolumn{1}{c}{ Species } & \multicolumn{1}{c}{ Organs } & \multicolumn{1}{c}{ Inhibitors } & Labeled precursors & References \\
\hline $\begin{array}{c}\text { Leucophaea } \\
\text { maderae }\end{array}$ & Leg regenerates ${ }^{\mathrm{a})}$ & TH $6040^{\mathrm{c})}$ & N-acetylglucosamine & Sowa and \\
Plodia & & Polyoxin $\mathrm{D}^{\mathrm{d})}$ & D-glucosamine & Marks (1975) \\
interpunctella & Wing imaginal disks & TH 6040 & D-glucose & Oberlander \\
& & Polyoxin D & & and \\
& & & & Leach (1974) \\
\end{tabular}

a) These from late instar nymphs were cultured in M20S medium containing $\beta$-ecdysone.

b) These from last instar larvae were cultured in modified Grace's medium containing $\beta$-ecdysone.

c) $\mathrm{TH} 6040$ [N-(4-chlorophenyl)- $\mathrm{N}^{\prime}-(2,6$-difluorobenzoyl) urea] is an inhibitor of chitin synthesis, but the site of action has yet to be determined.

d) Polyoxin $\mathrm{D}$ is an inhibitor of the chitin synthetase.

e) Cytochalasin B is an inhibitor of sugar transport.

の ${ }^{14} C$-acetyl glucosamine (AGA) の取り込みが ${ }^{14} C$ glucosamine (GA) よりも 10 倍ほど高くなる.) でキチ ン合成阻害剂である $\mathrm{TH}$ 6040, polyoxin D を培地に加 え，キチン合成を調べた時の条件，および Oberlander と Leach (1974) $)^{9}$ による Plodia interpunctella (ノシメコ クガ）の wing disks (翅の原基) を用いて同様の実験を 行なった条件をまとめたものである.すなわち，阻害剤 の作用を知るために標識した glucosamine や acetylglucosamine を培地に加え，それらの取り込みからその 作用を検討したものである. Sowa と Marks (1975) ${ }^{8)}$, Marks と Sowa $(1974,1976)^{10,11)}$ は TH 6040 あるい は polyoxin D の存在下で ${ }^{14} \mathrm{C}-\mathrm{GA}$ や ${ }^{14} \mathrm{C}$-AGA をと り込ませると ${ }^{14} C$-UDP-AGA のみが，どちらの場合に もできることから，TH 6040 と folyoxin D は組織に同 じように作用すると考えた. しかし， ${ }^{14} C$-UDP-AGA の 生成, 蓄積については, まだ, はっきりとした結論を導 くに足りるデーターが得られていないので，そのため にも培養系は有力な手段となりうるであろう。一方, Oberlander と Leach (1974) $\left.{ }^{9}\right)$ は, ノシメコクガの趐の 原基を使い cytochalasin $\mathrm{B}$ と polyoxin $\mathrm{D}$ を培地に加 え，キチン合成阻害について調べたところ，これらの薬 剤はクチクルの沈積を阻害したと報告しているが，この 培養系では，クチクルの沈積をメルクマールにしてお り，キチンそのものが生成されたか否かについては，明 記していない. 培養系ではないが, polyoxin D c chitin synthetase の関係については, Hori ら (1974)12) の仕事 がある. また, TH 6040 と chitin synthesis との関係に ついては, Post ら (1974)13) の仕事があるので参考にし ていただきたい.

Marks と Sowa $(1976)^{11)}$ は in vitro でゴキブリの再 生組織を使って captan, kitazin-p, parathion, quintazene
とキチン合成について興味深い結果を得ている.

\section{3. 精巣の培養と不妊剤}

1915 年 Goldschmidt がセクロピアガの spermatocyst の精子形成を in vitro で観察して以来，多くの研究者 によって生殖巣の培養が行なわれてきている14,15). 以下 に八木らが行なっている精巣の培養の例を示す.

1) 培 地

培地の調整は $\alpha$-エクダイソンをエタノールに溶か し，溶媒とともに Grace’s の培地（GIBCO 製）に加え た. 溶媒の濃度は培地の $1 / 100$ 以下になるようにした。 metepa と hempa の濃度は $0.5 \mu \mathrm{g}$ と $1.0 \mu \mathrm{g} / \mathrm{ml}$ にな るようにそれぞれ $\alpha$-エクダイソン $(0.5 \mu \mathrm{g} / \mathrm{ml})$ を含む Grace’s の培地で調整された.

2) 培養容器

Mitsuhashi と Maramorosch (1964) ${ }^{16)}$ が考案した培養 容器と同じ型のものを大小 2 種類用いた. すなわち, 直 径 $25 \mathrm{~mm}$, 高さ $10 \mathrm{~mm}$. あるいは直径 $15 \mathrm{~mm}$ 高さ 4 $\mathrm{mm}$ のガラス製リングである.このリングの下端をカバ ーグラスで封じ，この容器の底に大リングでは 0.15〜 $0.30 \mathrm{ml}$ ，小リングの場合には $0.04 \mathrm{ml}$ の培地を加え, 組織を移した後, 上端をカバーグラスで封じ（いわゆる sitting drop culture) $25^{\circ} \mathrm{C}$ に保存した.

3) 培養操作

Fig. 1 に虫の殺菌から組織の摘出, 培地に移すまで の行程を示した. 虫は無菌的に人工飼育されたものが良 い.

このようにしてヨトウが休眠蛹 3 日目の精巣を $\alpha$-エ クダイソン $(5 \mu \mathrm{g} / \mathrm{ml})$ を含む培地で 7 日間培養し, 精巣 を破さ spermatocysts の発達を観察すると, 精子形成 (spermatocytes が伸長した spermatids になること) が 
Insect

Immerse it in $0.05 \%$ mercuric chloride for $2 \mathrm{~min}$ $\downarrow$

Immerse it in $70 \%$ ethanol for $5 \mathrm{~min}$ $\downarrow$

Rinse twice with sterile distilled water $\downarrow$

Take out the organ from the sterilized insect under the dissecting microscope

$\downarrow$

Place the organ in a small petri dish or Maximov slide filled with insect Ringer's solution or RingerTyrode's salt solution ${ }^{16)}$

$\downarrow$

Place the organ in a culture well filled with culture medium

Incubate at $25^{\circ} \mathrm{C}$

Fig. 1 The technical methods for the tissue culture.

著しく促進され，伸長した spermatocysts がみられた この系を使って, metepa と hempa を作用させて精細 胞の発達を調べた ${ }^{18)}$. 結果は Table 2 に示したように, metepa は hempa よりも spermiogenesis（精子変態, 精 子成熟）を抑制した。 しかし， metepa や hempa の作用 は精巣鞘に作用した結果なのか，直接 spermatocysts に 作用した結果なのか，まだ明らかではない。

\section{Spermatocyst と JH}

カイコが幼虫の spermatocysts を培養して Juvenile
Hormone $(\mathrm{JH})$ が spermatogenesis とくに, spermiogenesis におよぼす影響を検討するとともに，JH の生物検定が 可能かについて調べた ${ }^{19)}$.

1) Spermatocyst

日 $122 \times$ 支 122 の $F_{1}$ で 4 齢 3 4 日目の個体を用 い, 精巣を摘出し, 培地中で精巣を微針で破いて中の spermatocysts を培地中に放出させた。

2）培 地

Grace’s の培地に必要に応じて 熱処理したカイコガ蛹 (1 日目)，ヨトウガ蛹 (3 日目) の血液を加えた. その 方法は，蛹から採血した血液を $60^{\circ} \mathrm{C}$ で，10 分間熱処 理をし，3000 rpm で 10 分間遠心分離してその上澄みを $0.45 \mu$ のミリポアフィルターでろ過してこれを一定量 (1/4 または 1/2) になるように Grace's の培地に加え た. JH は JH-I を用い, アセトン: エタノール=1: 1 の溶媒に溶かしたものを培地に加えけんだくさせて用い た. 濃度は $0.5,5,50 \mu \mathrm{g} / \mathrm{ml}$ にし，溶媒は培地の $1 / 200$ 以下になるように調整し，5日間培養した。

結果は Table 3 に示すように Grace's の培地のみで 培養した場合， spermatocysts はすべて pyriform spermatocysts（一部の spermatocyte が伸長し始めた状態） の形状で発育は止まってしまい，その後の発達は，まっ たく見られなかった．血液を培地に加えた場合には， spermiogenesis (spermatids が伸長する) が急激に促進 され，長く伸びた spermatocysts に発達した.この培 地に JH を加えると，JH の濃度が高まるにつれてよ り強く spermatocysts の伸長が抑制されることがわかっ た。

Table 2 Inhibition of spermiogenesis in M. brassicae by chemosterilants in vitro. ${ }^{18)}$

\begin{tabular}{|c|c|c|c|c|c|c|c|c|c|c|c|}
\hline \multirow{2}{*}{ Treatment ${ }^{a)}$} & \multirow{2}{*}{$\begin{array}{c}\text { No. of } \\
\text { exp. }\end{array}$} & \multicolumn{5}{|c|}{ Spermiogenesis } & \multicolumn{5}{|c|}{$\begin{array}{l}\text { Degeneration of spherical } \\
\text { spermatocysts }{ }^{\mathrm{b})}\end{array}$} \\
\hline & & - & \pm & + & ++ & +++ & - & \pm & + & ++ & +++ \\
\hline$\alpha$-ecdysone (control) & 5 & 0 & 0 & 0 & 0 & 5 & 4 & 0 & 1 & 0 & 0 \\
\hline$\alpha$-ecdysone + metepa & 5 & 0 & 0 & 0 & 4 & 1 & 0 & 0 & 0 & 1 & 4 \\
\hline$\alpha$-ecdysono + hempa & 5 & 0 & 0 & 0 & 1 & 4 & 0 & 0 & 4 & 1 & 0 \\
\hline
\end{tabular}

a) Grace's medium containing $5 \mu \mathrm{g} / \mathrm{ml}$ of $\alpha$-ecdysone was used as a basic culture medium and $0.5 \mu \mathrm{g} / \mathrm{ml}$ of metepa or $1.0 \mu \mathrm{g} / \mathrm{ml}$ of hempa was added to the medium.

b) Seven days after cultivation, each testis was dissected to examine development or degeneration of spermatocysts.

Spermiogenesis :

-: spherical spermatocysts only; \pm : mixture spherical spermatocysts and pyriform spermatocysts; + : elongated spermatocysts are less than $10 \%$; ++ : elongated spermatocysts are more than $10 \%$ but less than $50 \% ;+++$ : elongated spermatocysts are more than $50 \%$.

Degeneration of spherical spermatocysts:

- : no degeneration; \pm : degeneration $<1 \%$; + : 1\%-10\%; ++ : $10 \%-50 \% ;+++$ : $>50 \%$. 
Table 3 Effects of $\mathrm{JH}-\mathrm{I}$ on spermiogenesis of Bombyx mori in vitro. ${ }^{19}$

\begin{tabular}{|c|c|c|c|c|c|c|}
\hline \multirow{2}{*}{$\begin{array}{l}\text { Concentr. of } \\
\left.\mathrm{JH} \text { in the medium }{ }^{\mathrm{a}}\right) \\
(\mu \mathrm{g} / \mathrm{ml})\end{array}$} & \multirow{2}{*}{$\begin{array}{l}\text { No. of } \\
\text { experiments }\end{array}$} & \multicolumn{5}{|c|}{ Spermiogenesis in the medium ${ }^{\mathrm{b})}$} \\
\hline & & - & \pm & + & ++ & +++ \\
\hline 0 (control) & 11 & 0 & 0 & 0 & 2 & 9 \\
\hline 0.5 & 6 & 0 & 0 & 0 & 2 & 4 \\
\hline 5 & 8 & 0 & 0 & 1 & 5 & 2 \\
\hline 50 & 4 & 4 & 0 & 0 & 0 & 0 \\
\hline G-M only & 10 & 8 & 2 & 0 & 0 & 0 \\
\hline
\end{tabular}

a) Composition of the medium: Grace's medium (G-M) $75 \%+$ heat treated blood of B. mori pupae $25 \%$.

b) Spermatocysts were cultivated for 5 days.

-: spherical spermatocysts; \pm : spherical spermatocysts and pyriform spermatocysts; + : elongated spermatocysts $<10 \% ;++$ : $\leqq 10 \%$ elongated spermatocysts $<50 \%$; +++ : elongated spermatocysts $\geqq 50 \%$.

\section{5. 生殖細胞と DDT}

生殖細胞に対する DDT の直接的な作用を調べるため に，ヨトウガの生殖細胞を用い，DDT のとり入みと， とり入み部位を調べた ${ }^{20)}$.

1) 培 地

${ }^{14} C$-DDT はエタノールに溶かし, Grace’s の培地に加 え $4 \times 10^{-6} \mathrm{M}$ にした.

\section{2) 生殖細胞}

ヨトウガ非休眠蛹（1日目）の精巣（10 個）の生殖細 胞を用いた．培養容器中で精巣を破き，生殖細胞を放出 させた後, ${ }^{14} C$-DDT を含む Grace’s の培地 $(0.2 \mathrm{ml})$ を 加え 3 時間, $25^{\circ} \mathrm{C}$ でインキュベートした.

3）生殖細胞のとり扱い方

培養後, 培地をとり除き, 細胞は遠心 (2000 rpm) し ながら 3 回洗浄した.とり込まれた 細胞中の ${ }^{14} C$-標識 物質は $0.1 \mathrm{~N} \mathrm{NaOH}$ で溶かし，一部を液体シンチレー ション・カウンターでカウントし, 同時に細胞蛋白質を Lowry 法6)を用いて測定した。 細胞表面に付着した標識 物質の除去には低濃度の Triton X-100を用いた。 た, おのおのの濃度の Triton X-100 洗液は 10 分間 $30^{\circ} \mathrm{C}$ で振盪しながらインキュベートし，2000 rpm で遠沈し， 上清を回収したものである. このディタージェントを使 う方法は Berkowitz 等 ${ }^{21)} よ り$ 紹介されているが，簡単 で手っとり早く, 細胞核を分離でき, 酵素実験にも利用 できるので便利である.

Table 4 に示すように, 順次, Triton X-100 の濃度を 上げると細胞表面に結合していると思われる標識物質が 次々と回収された. 最後に細胞に残ったと思われる標識 物質は，全標識物質の $50.4 \%$ であった ${ }^{20)}$. Triton X-
Table 4 Liberation of ${ }^{14} C$-DDT from cell surface after treatment with various concentrations of Triton X-100 (0.0001-0.01\%)

\begin{tabular}{lrc}
\hline $\begin{array}{c}\text { Concentration of } \\
\text { Triton X-100 } \\
(\%)\end{array}$ & \multicolumn{2}{c}{ Radioactivity liberated } \\
\cline { 2 - 3 }$(\%)$ & 1108 & 9.9 \\
\hline (Medium) & 40 & 0.4 \\
$(0.9 \% \mathrm{NaCl})$ & 412 & 3.6 \\
0.0001 & 228 & 2.0 \\
0.0005 & 348 & 3.1 \\
0.001 & 784 & 6.9 \\
0.005 & 2686 & 23.8 \\
$0.01^{*}$ & & 50.4 \\
\hline Radioactivity remained & 5694 & \\
in the cells** & & \\
\hline
\end{tabular}

* This dose of Triton X-100 caused no visible disruption to the cells.

** Protein content digested with $5 \mathrm{ml}$ of $0.1 \mathrm{~N}$ $\mathrm{NaOH}$ at room temperature was $375 \mu \mathrm{g} /$ culture well.

100 を使った Petrovic 等の実験では，0.05\%の Triton でマウスの L-細胞の外側の膜が消失し，まれには，核 が細胞から離れてしまう現象を報告し，0.3\% に濃度を 上げても，核はよく保持されていたと報告している ${ }^{22)}$.

今後は DDTのとり込みや残留性ばかりでなく, 精細 胞の分化に及ぼす DDT の影響を調べてみたい。こと に，最近，エクダイソンを培地に加えなくとも化学的に 組成のわかっている Grace's の培地だけでヨトウガ休眠 蛹の spermiogenesis を導く系を見いだしたので23)，より 直接的に spermiogenesisにお汓る薬物の作用を検討して 


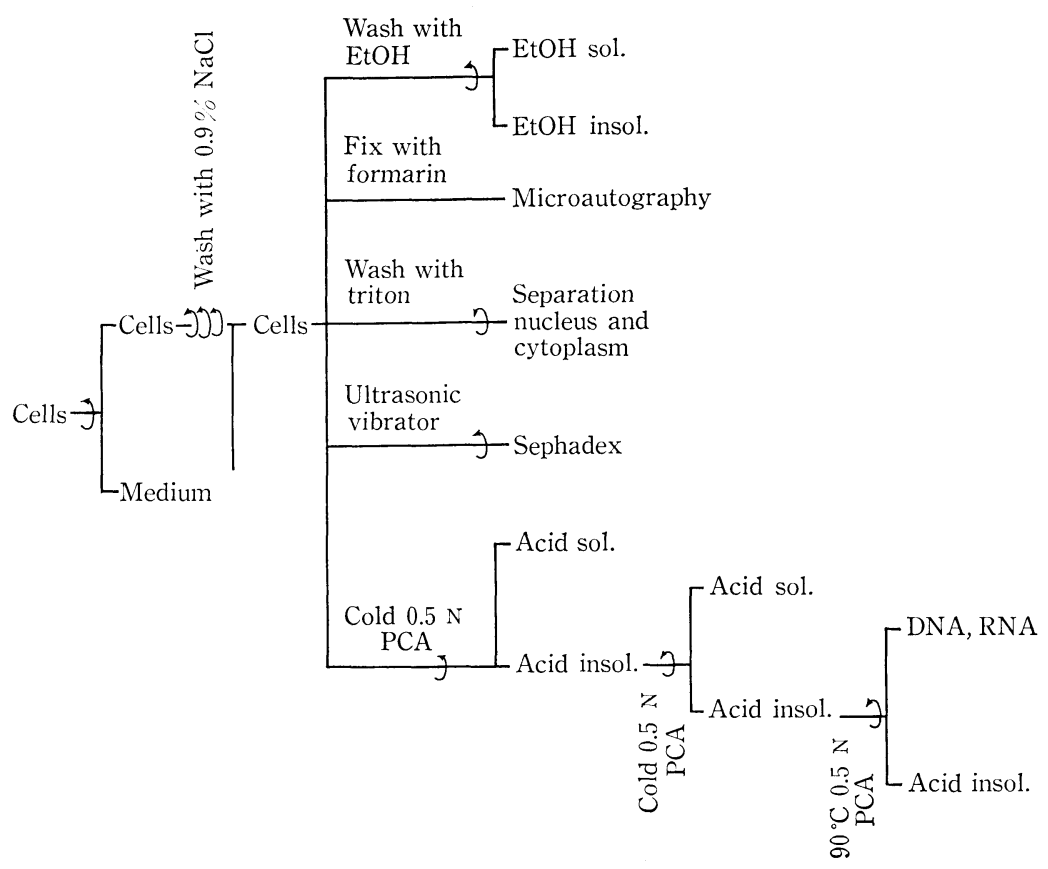

Fig. 2 The chemical analytical methods for the tissue culture.

(動物組織培養法 ${ }^{24)}$ 上り作成)

いくことができると思われる.

\section{6. 薬理作用を調べるための手法}

in vitro でおこる現象は，培地に含まれる化学物質の 溶解度, 細胞への物質の透過性, 有効部位に達するまで の代謝等が複雑に関係しあって, 細胞增殖あるいは細胞 毒性として現われてくるので，さらに詳細な検討が必要 となってくる. その機構を解明するためには，Fig. 2 に 示したような手法が有効であると思われるので参考にし ていただきたい24).

\section{引用 文 献}

1) M. Murakami \& J. Fukami: Bull. Environ. Contam. Toxicol. 11, 184 (1974)

2) M. Murakami \& J. Fukami: Bull. Environ. Contam. Toxicol. 15, 425 (1976)

3) M. Murakami \& J. Fukami: Bull. Environ. Contam. Toxicol. 19, 423 (1978)

4) M. Murakami \& J. Fukami: Bull. Environ. Contam. Toxicol. 21, 印刷中

5) 村上 誠：農薬科学 2, 1 (1974)

6) O. H. Lowry, N. J. Rosebrough, A. L. Farr \& R. J. Randall: J. Biol. Chem. 193, 265 (1951)

7) V. I. Oyama \& H. Eagle: Proc. Soc. Exp. Biol. Med. 91, 305 (1956)
8) B. A. Sowa \& E. P. Marks: Insect Biochem. 5, 855 (1975)

9) H. Oberlander \& C. E. Leach: Proc. 1st Int. Congr. Stored Products Entomol. in Georgia, USA, October 7, p. 651, 1974

10) E. P. Marks \& B. A. Sowa: "Mechanism of Pesticide Action, ACS Sym. Series No. 2." Am. Chem. Soc. Publishers, Washington, DC, p. 145, (1974)

11) E. P. Marks \& B. A. Sowa: “The Insect Integument." ed. by H. R. Hepburn, Elsevier Scientific Publishing Company, p. 339, 1976

12) M. Hori, J. Eguchi \& K. Kakiki: J. Antibiot. 27, 260 (1974)

13) L. Post, B. deJong \& W. Vincent: Pestc. Biochem. Physiol. 4, 473 (1974)

14) J. Demal and A. M. Leloup: “Invertebrate Tissue Culture. Vol. 2." Academic Press, New York and London, p. 3, 1972

15) E. P. Marks: Gen. Comp. Endocrinol. 15, 289 (1970)

16) J. Mitsuhashi \& K. Maramorosch: Contrib. Boyce Thompson Inst. 22, 435 (1964)

17) T. Fukushima \& S. Yagi: Appl. Entomol. Zool. 10, 220 (1975)

18) I. Nakayama, S. Yagi \& N. Agui: Appl. Entomol. Zool. 11, 141 (1975)

19) S. Yagi \& T. Fukushima: Appl. Entomol. Zool. 
10, 77 (1975)

20) T. Shimizu, M. Murakami \& J. Fukami: J. Pesticide Sci. 4, 67 (1979)

21) D. M. Berkowitz, T. Kakefuda \& M. B. Sporn: J. Cell Biol. 42, 851 (1969)

22) S. Petrovic, O. Djordjevic \& L. Kostic: Exp.
Cell Res. 52, 419 (1968)

23) T. Shimizu and S. Yagi: Appl. Entomol. Zool. 13, 278 (1978)

24）黒田行昭：動物組織培養法 共立出版， p. 269， (1974) 